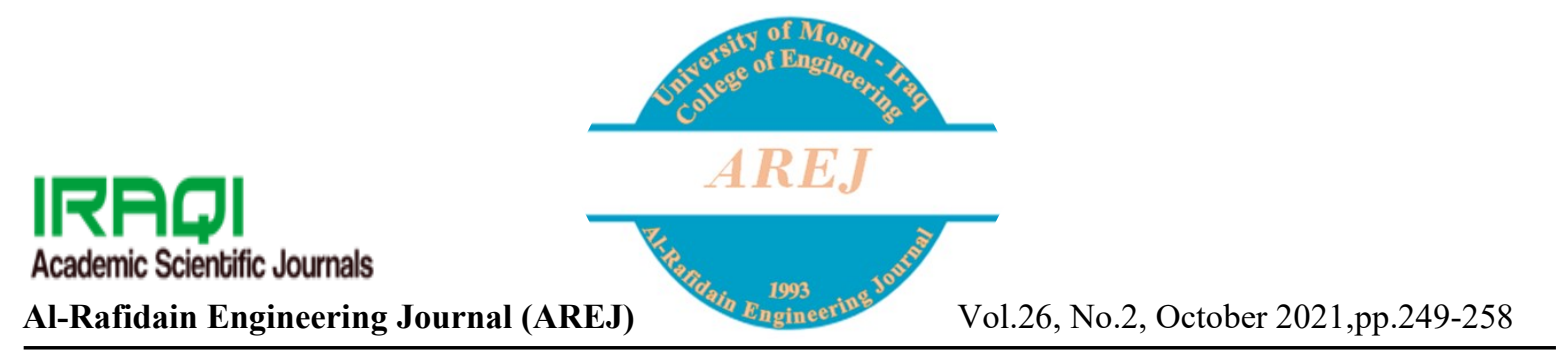

\title{
Infiltration and Some Physical Properties of soil
}

\author{
Haqqi I. Yasin \\ haqqiismail56@gmail.com
}

\author{
Entesar M. Ghazal \\ entesarzal@gmail.com
}

Dams and Water Resources Engineering Department, Collage of Engineering, University of Mosul

Received: $14 / 4 / 2020$

Accepted: 3/8/2021

\begin{abstract}
The research aims to study the effect of some physical properties of the soil as components of sand, silt, clay, bulk density, and the initial soil moisture on cumulative infiltration depth, infiltration rate, and basic infiltration rate. Depending on data from 31 laboratory infiltration tests represented by 516 values for cumulative infiltration depth and cumulative infiltration time, including a wide range of changes in soil physical properties. Using the statistical program (SPSS) and by applying the nonlinear regression method, the best empirical equation has been derived to estimate the cumulative infiltration depth, with a determination coefficient of 0.975, as a function of some physical properties of soil and in the form of Kostakov's equation to include estimation of basic infiltration rate.
\end{abstract}

Keywords: Infiltration, Initial soil moisture, bulk density, Soil texture.

This is an open-access article under the CC BY 4.0 license (http://creativecommons.org/licenses/by/4.0/). https://rengj.mosuljournals.com

\section{INTRODUCTION}

Infiltration is the process of water entering the soil through its surface. The main forces that cause the infiltration process are the capillary forces that originate from the adhesion forces between water molecules and soil particles and the Earth's gravitational force $[\mathbf{2} \cdot \mathbf{1}]$.

The infiltration process is affected by many factors, including soil bulk density, initial soil moisture, soil texture, soil type, soil structure, soil organic matter, and other physical and chemical properties of the soil [3]. Kostiakov equation is one of the oldest and most common positivist equations to describe infiltration of water in soil [4]:

$\mathbf{D}=\mathbf{C} \mathbf{T}^{\mathbf{M}}$

Where $\mathrm{D}$ is the cumulative infiltration depth $(\mathrm{mm}), \mathrm{T}$ is the cumulative infiltration time ( $\mathrm{min}$ ), $\mathrm{C}$ and $\mathrm{M}$ are constants. To describe the infiltration rate, equation (1) is differentiated with respect to time as follows [1]:

$$
I=60 * C * M * T^{M-1}
$$

Where $\mathbf{I}$ is the infiltration rate ( $\mathrm{mm} /$ hour). The basic infiltration rate $\mathrm{Ib}(\mathrm{mm} /$ hour $)$ is obtained from equation (2) at infiltration time $\mathrm{T}$ equals the infiltration time $\mathrm{Tb}$ (min), which is found as follows [1]:

$\mathbf{T b}=|600 *(\mathrm{M}-1)|$

Several mathematical models describe the infiltration and the factors affecting it. Two equations were devised to estimate the cumulative infiltration depth for different initial moisture levels and from higher to lower moisture levels or vice versa [5]. 
Multiple linear relationships were found between soil infiltration rate and some physical properties such as moisture content, silt content, clay content, bulk density, and soil organic matter using data from 100 field infiltration tests [6].

In addition, multiple linear relationships were found between the basic infiltration rate and some physical properties, including the moisture content, proportions of soil components of sand, silt, clay, bulk density, soil particle density, and soil organic carbon using data for 25 field infiltration tests in loam and loamy sand and sandy loam soils [7].

In a laboratory study, fine and coarse soil were mixed in seven different ratios (fine/coarse). The infiltration test was performed for each mixture to determine the infiltration rate over time. A polynomial equation was proposed. Results show that when the mixing ratio is known, the infiltration rate can be estimated as a function of this ratio and time, where other factors are constant at the fine mixing ratio [8].

Despite the numerous research devised an empirical equation to study the infiltration that covers some of the physical factors affecting the water infiltration, it expresses either the cumulative infiltration depth and the infiltration rate or the basic and final infiltration rate. There is no empirical equation covering several physical factors affecting the cumulative infiltration depth, infiltration rate, and basic infiltration rate.

Therefore, the study deals with devising an equation that includes cumulative infiltration depth, infiltration rate, and basic infiltration rate in the form of Kostakov's equation. Also, it covers the effect of physical factors within the equation coefficient so that the basic infiltration rate can be easily expressed.

\section{MATERIALS AND METHODS:}

\subsection{Data:}

Data were approved for 31 laboratory infiltration tests conducted by $[8,9,10,11,12$, $13,14,15]$, represented by cumulative infiltration depth and cumulative infiltration time. Table (1) displays the soil texture, the percentages of soil
Table (1): Soil texture, proportions of soil components, initial soil water content, and soil bulk density for all infiltration lab tests.

\begin{tabular}{|c|c|c|c|c|c|c|}
\hline 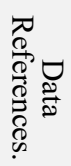 & 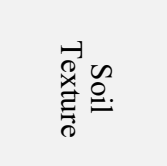 & 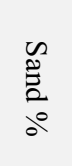 & $\underset{\partial^{0}}{\stackrel{\mathscr{C}}{\rightleftarrows}}$ & $\begin{array}{l}\Omega \\
\stackrel{2}{<} \\
0^{\circ}\end{array}$ & 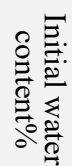 & 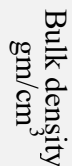 \\
\hline \multirow{2}{*}{ [9] } & sandy loam & 66.7 & 26.7 & 6.6 & 5.2 & 1.30 \\
\hline & Silty clay & 11.3 & 42.6 & 47.1 & 6.7 & 1.33 \\
\hline \multirow{2}{*}{ [10] } & sandy loam & 66 & 27.5 & 6.5 & 2.7 & 1.35 \\
\hline & loam & 51.6 & 32.7 & 15.7 & 4.5 & 1.33 \\
\hline \multirow{3}{*}{ [11] } & sandy loam & 75 & 17 & 8 & 3.2 & 1.40 \\
\hline & loam & 52 & 33 & 15 & 4.1 & 1.35 \\
\hline & $\begin{array}{c}\text { Silty clay } \\
\text { loam }\end{array}$ & 13 & 50 & 37 & 6.0 & 1.33 \\
\hline \multirow{6}{*}{ [12] } & Silt loam & 32 & 56 & 12 & 12.1 & 1.30 \\
\hline & Silt loam & 32 & 56 & 12 & 18.2 & 1.30 \\
\hline & Silt loam & 1 & 85 & 14 & 11.0 & 1.28 \\
\hline & Silt loam & 1 & 85 & 14 & 19.7 & 1.28 \\
\hline & silt & 2 & 92 & 6 & 6.5 & 1.25 \\
\hline & silt & 2 & 92 & 6 & 18.5 & 1.25 \\
\hline \multirow{4}{*}{ [13] } & sandy loam & 70 & 16 & 14 & 3.3 & 1.65 \\
\hline & sandy loam & 70 & 16 & 14 & 9.0 & 1.65 \\
\hline & $\begin{array}{l}\text { Silty clay } \\
\text { loam }\end{array}$ & 15 & 48 & 37 & 11.0 & 1.65 \\
\hline & Silty clay & 7 & 47 & 46 & 11.2 & 1.60 \\
\hline \multirow{9}{*}{ [14] } & loam & 50 & 40 & 10 & 11.2 & 1.40 \\
\hline & loam & 50 & 40 & 10 & 16.8 & 1.40 \\
\hline & loam & 50 & 40 & 10 & 22.4 & 1.40 \\
\hline & clay loam & 39 & 31 & 30 & 12.6 & 1.35 \\
\hline & clay loam & 39 & 31 & 30 & 17.6 & 1.35 \\
\hline & clay loam & 39 & 31 & 30 & 24.2 & 1.35 \\
\hline & Silty clay & 12.5 & 45 & 42.5 & 14.2 & 1.30 \\
\hline & Silty clay & 12.5 & 45 & 42.5 & 19.6 & 1.30 \\
\hline & Silty clay & 12.5 & 45 & 42.5 & 24.2 & 1.30 \\
\hline \multirow{3}{*}{ [15] } & Loamy sand & 79.2 & 11.2 & 9.6 & 5.6 & 1.43 \\
\hline & Silt loam & 10.4 & 79.4 & 10.2 & 19.0 & 1.39 \\
\hline & Silt loam & 32.8 & 54 & 13.2 & 2.0 & 1.40 \\
\hline \multirow{2}{*}{ [16] } & sandy loam & 68 & 29.5 & 2.5 & 3.3 & 1.39 \\
\hline & Silty clay & 8 & 55 & 37 & 5.8 & 1.36 \\
\hline
\end{tabular}


components such as sand, silt, and clay, in addition to initial soil moisture and bulk density adopted in soil compaction for all tests.

\subsection{Infiltration estimation:}

With 516 values for cumulative infiltration time $\mathrm{T}$ (minutes), volumetric initial soil moisture $\mathrm{Mc}$ and bulk density of $\mathrm{Bd}$ (g/cm3) and percentage of soil components of sand $\mathrm{Sa}$, Silt Si, and clay Cl. Using the Special Program for Statistical System (SPSS), and by applying nonlinear regression method, the best empirical equation was devised to estimate the cumulative filtration depth as a function of the above factors and in the following form:

$$
\begin{gathered}
\mathrm{D}=2.403 * \mathrm{~T}^{0.539} * \mathrm{Bd}^{-1.934} * \mathrm{Mc}^{-0.25} *[51.734 * \\
\left.\mathrm{Sa}{ }^{12.366}-3.271 * \mathrm{Si}^{22.978}-1.169 * \mathrm{Cl}+2.24\right] \\
\ldots \ldots \ldots . . \mathrm{R}^{2}=0.975
\end{gathered}
$$

The infiltration rate is obtained by differentiating equation 4 with respect to time. It is expressed in $\mathrm{mm}$ /hour as follows:

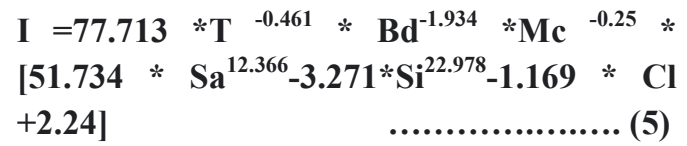

Since the formula of Equation 4 is similar to the formula of Equation 1, the basic infiltration time is equal to 276.6 minutes. Thus, the basic infiltration rate $\mathbf{I b}$ in $\mathrm{mm} /$ hour is expressed as follows:

$$
\begin{aligned}
& \mathrm{Ib}=5.818 * \mathrm{Bd}^{-1.934} * \mathrm{Mc}^{-0.25} *[51.734 * \mathrm{Sa} \\
& \left.12.366-3.271 * \mathrm{Si}^{22.378}-1.169 * \mathrm{Cl}+2.24\right] \ldots(6)
\end{aligned}
$$

\section{RESULTS AND DISCUSSION}

Figure (1) compares the cumulative infiltration depth measured from the tests mentioned above and the estimated cumulative infiltration depth from the inferred equation. Equations 4, 5, and 6 were adopted in drawing relationships to illustrate the effect of initial soil moisture, soil bulk density, and soil texture on the cumulative infiltration depth, the infiltration rate, and the basic infiltration rate.

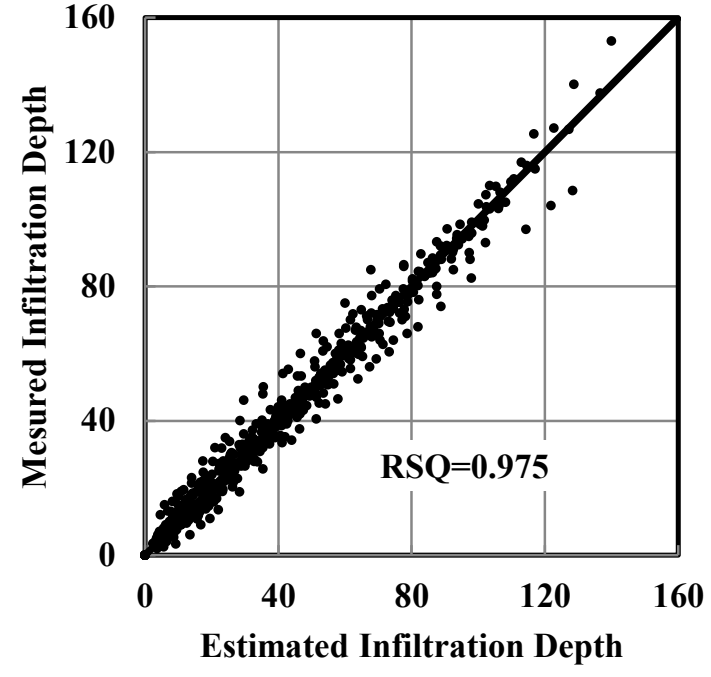

Figure (1): The comparison between the measured infiltration depths and estimated from equation (4).

3.1. Effect of initial soil moisture on infiltration:

Figure (2) shows the relationship between the cumulative infiltration depth and time in loamy soil having a bulk density of $1.45 \mathrm{~g} / \mathrm{cm}^{3}$ and for different levels of initial soil moisture. It is evident from the Figure that the cumulative infiltration depth increases with time and increases with the decrease in the initial moisture; that increase is greater as the initial moisture decreases. Figure (3) presents the relationship of the infiltration rate with time in loamy soil having a bulk density of $1.45 \mathrm{~g} / \mathrm{cm}^{3}$ and for different levels of the initial soil moisture. The Figure shows that the infiltration rate decreases with time and the increase in initial soil moisture. Figure (4) presents the relationship between the basic infiltration rate and the change in bulk density of loamy soil for different soil moisture levels. It is evident from the Figure that the basic infiltration rate decreases with the increase in the bulk density and that at any specific value of the bulk density. In contrast, the basic infiltration rate increases with the decrease in the initial soil moisture, and that increase is greater at the lower initial moisture.

Figure (5) presents the relationship between relative infiltration and relative initial soil moisture, relative infiltration can be a relative cumulative infiltration depth, relative infiltration rate, or relative basic infiltration rate. 


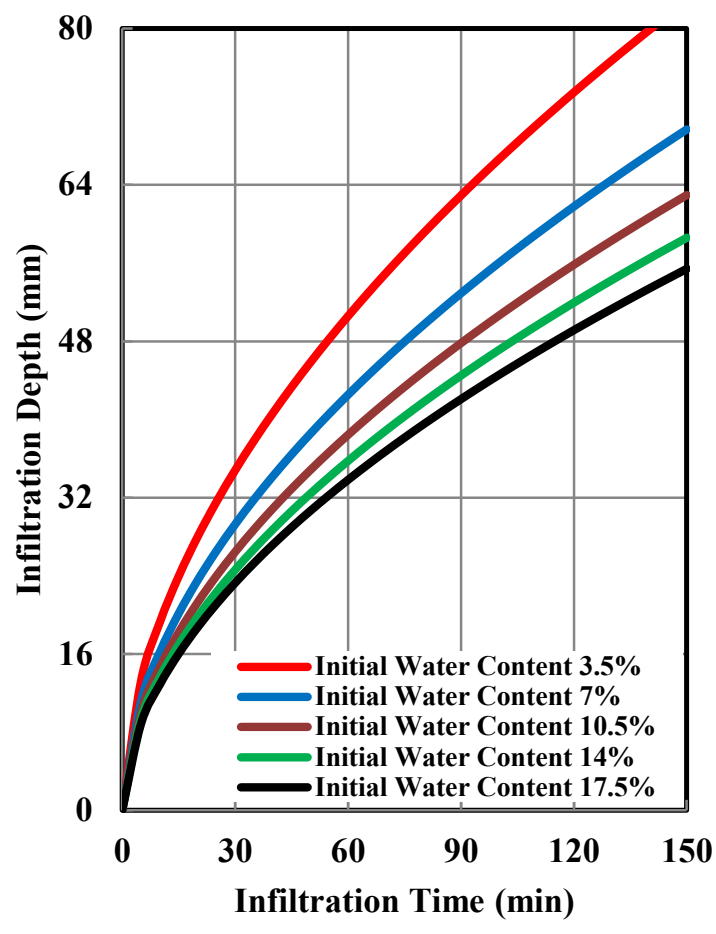

Figure (2): The relationship of the cumulative infiltration depth with time in loamy soil having a bulk density of $\mathbf{1 . 4 5}$ $\mathrm{g} / \mathrm{cm}^{3}$ and for different levels of the initial soil water content.

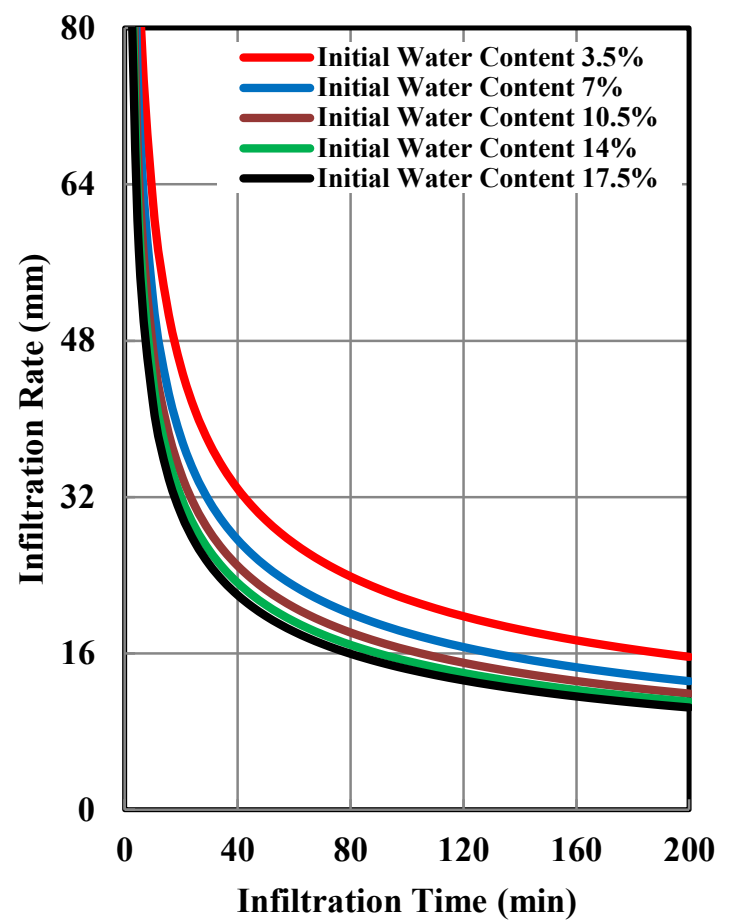

Figure (3): The relationship of the infiltration rate with time in loamy soil having a bulk density of $1.45 \mathrm{~g} / \mathrm{cm}^{3}$ and for different levels of the initial soil water content.

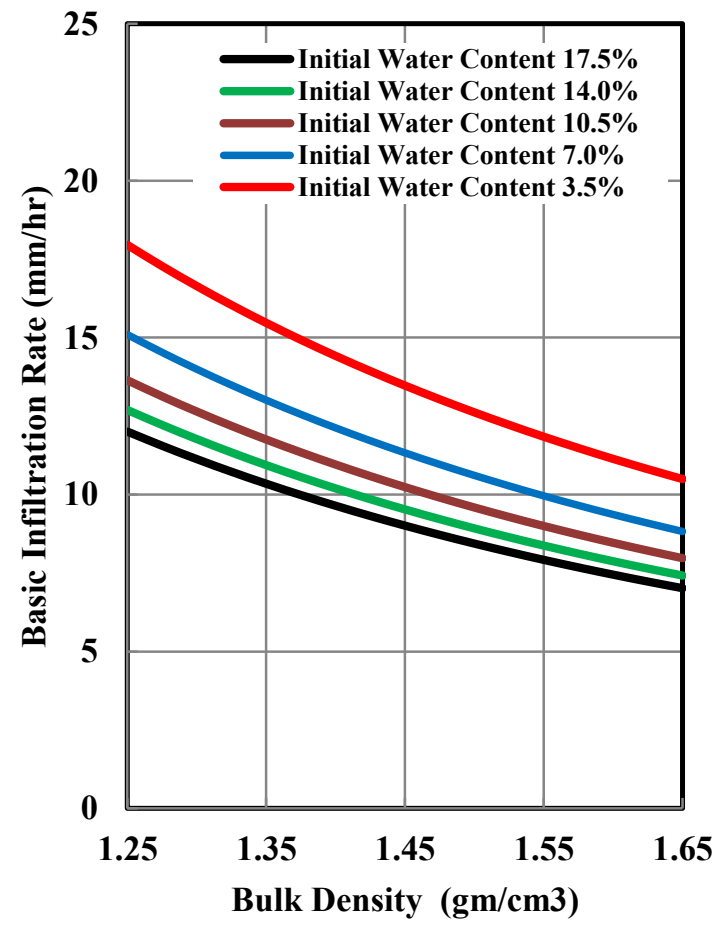

Figure (4): The relationship of the basic infiltration rate with bulk density in loamy soil for different levels of the initial soil moisture content.

The values for the cumulative infiltration depth $\left(D_{0}, D_{1}, D_{2}, D_{3, \ldots}\right)$ at the same infiltration time, or the values for the infiltration rate $\left(\mathrm{I}_{0}\right.$, $\left.\mathrm{I}_{1}, \mathrm{I}_{2}, \mathrm{I}_{3}, ..\right)$ at the same infiltration time. Or the values of the basic infiltration rate $\left(\mathrm{Ib}_{0}, \mathrm{Ib}_{1}\right.$, $\left.\mathrm{Ib}_{2}, \mathrm{Ib}_{3}, ..\right)$ at soil initial moisture $\left(\mathrm{Mc}_{0}, \mathrm{Mc}_{1}\right.$, $\left.\mathrm{Mc}_{2}, \mathrm{Mc}_{3}\right)$. The relative values of the accumulative infiltration depth are $\left(\frac{D_{0}}{D_{0}}, \frac{D_{1}}{D_{0}}, \frac{D_{2}}{D_{0}}, \frac{D_{3}}{D_{0}}, \ldots\right)$. The relative values of the infiltration rate $\left(\frac{I_{0}}{I_{0}}, \frac{I_{1}}{I_{0}}, \frac{I_{2}}{I_{0}}, \frac{I_{3}}{I_{0}}, \ldots\right)$. The relative values of the basic infiltration rate $\left(\frac{I b_{0}}{I b_{0}}, \frac{I b_{1}}{I b_{0}}, \frac{I b_{2}}{I b_{0}}, \frac{I b_{3}}{I b_{0}}, \ldots\right)$. Moreover, the relative values of the initial soil moisture $\left(\frac{\mathrm{Mc}_{0}}{\mathrm{Mc}_{0}}, \frac{\mathrm{Mc}_{1}}{\mathrm{Mc}_{0}}, \frac{\mathrm{Mc}_{2}}{\mathrm{Mc}_{0}}, \frac{\mathrm{Mc}_{3}}{\mathrm{Mc}_{0}}, \ldots\right)$. Based on equations 4 and 5 at the same infiltration time and equation 6 , the following equation is obtained:

$\frac{D_{i}}{D_{0}}=\frac{I_{i}}{I_{0}}=\frac{I b_{i}}{I b_{0}}=\left[\frac{M c_{i}}{M c_{0}}\right]^{-0.25}$

Figure (5) shows that the relative infiltration, whether it is a relative cumulative infiltration depth, relative infiltration rate, or relative basic infiltration rate, decreases clearly with the increase in the relative initial moisture according to equation (7). 


\subsection{Effect of bulk density on infiltration}

Figure (6) presents the relationship of the cumulative infiltration depth with time in loamy soil having initial moisture of $10.5 \%$ and for different values of bulk density. The Figure shows that the cumulative infiltration depth increases with time and with a decrease in bulk density.

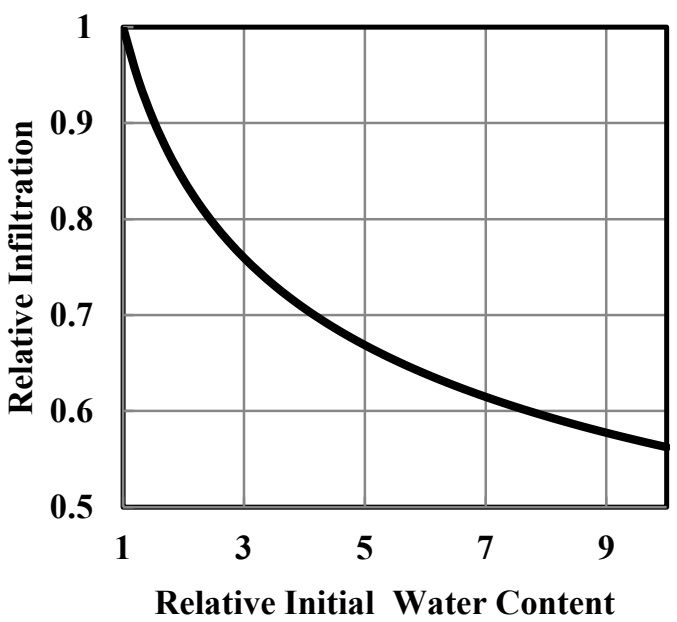

Figure (5): The relationship of the relative infiltration with the relative initial water content.

Figure (7) shows the relationship between infiltration rate and time of loamy soil with an initial soil moisture content of $10.5 \%$ and for different bulk density values. The infiltration rate decreases with time and an increase in bulk density. Figure (8) also shows the relationship between the basic infiltration rate with the initial soil moisture of loamy soil for different levels of soil bulk density. It is evident from the Figure that the basic infiltration rate decreases with the increase in the initial soil moisture and that at any specific value of the initial soil moisture. The basic infiltration rate increases with time and a decrease in bulk density. Figure (9) shows the relationship between relative infiltration with relative bulk density, relative infiltration, which was defined above, and the relative values of soil bulk density are $\left(\frac{B d_{0}}{B d_{0}}, \frac{B d_{1}}{B d_{0}}, \frac{B d_{2}}{B d_{0}}, \frac{B d_{3}}{B d_{0}}\right)$. Based on equations 4 and 5 , and at the same infiltration time and equation 6 results:

$\left.\frac{D_{i}}{D_{0}}=\frac{I_{i}}{I_{0}}=\frac{I b_{i}}{I b_{0}}=\frac{B d_{i}}{B d_{0}}\right]^{-1.934}$

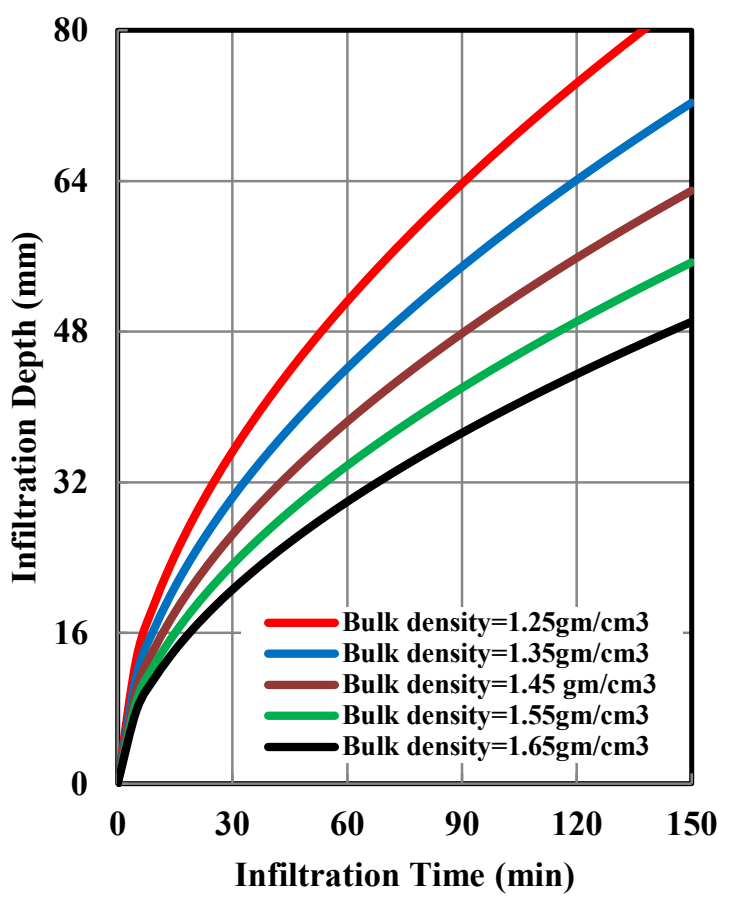

Figure (6): The relationship of the cumulative infiltration depth with time in loamy soil having initial soil moisture content of $10.5 \%$ and for different values of bulk densitv.

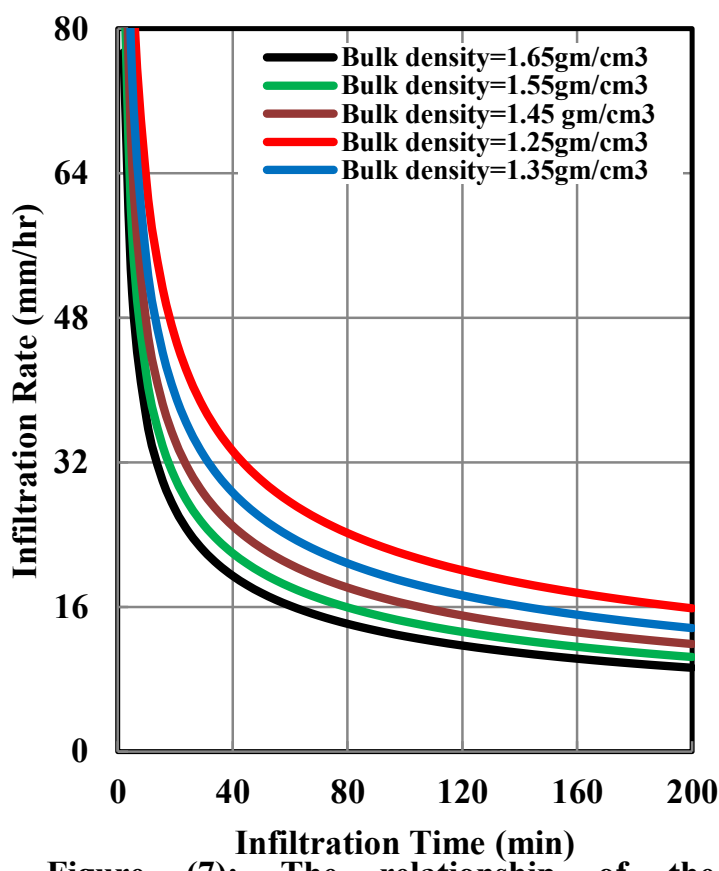

Figure (7): The relationship of the infiltration rate with time in loamy soil having initial soil moisture content of $10.5 \%$ and for different values of bulk density. 


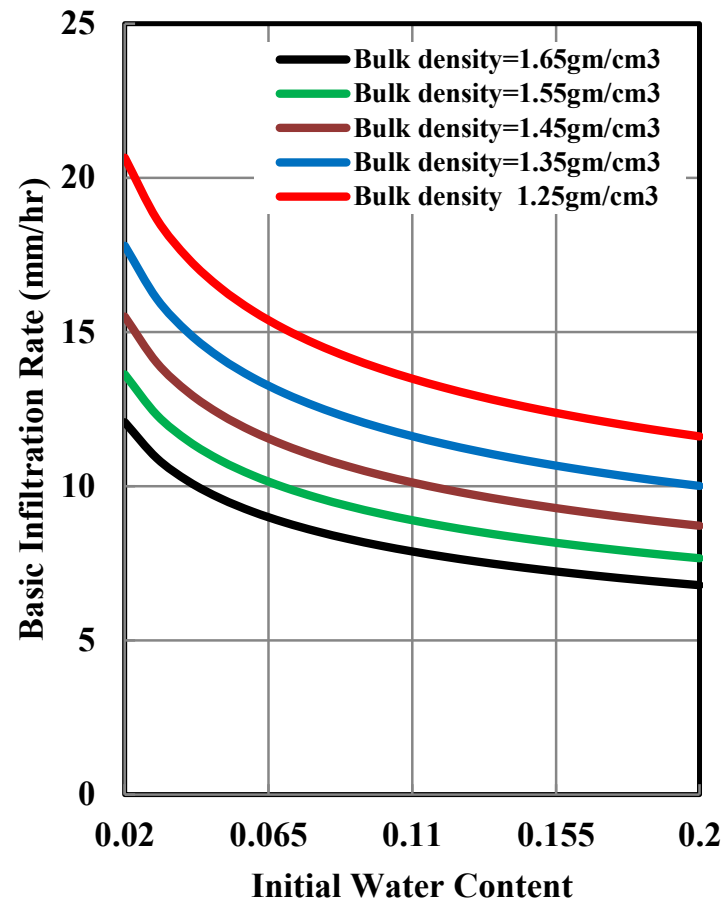

Figure (8): The relationship of the basic infiltration rate with the initial soil moisture content in loamy soil for different values of bulk density.

Equation (8) is shown in Figure (9), it is clear from Figure (9) that the relative infiltration, whether it is relative cumulative infiltration depth, relative infiltration rate, or relative basic infiltration rate, decreases with increasing relative bulk density according to equation 8 .

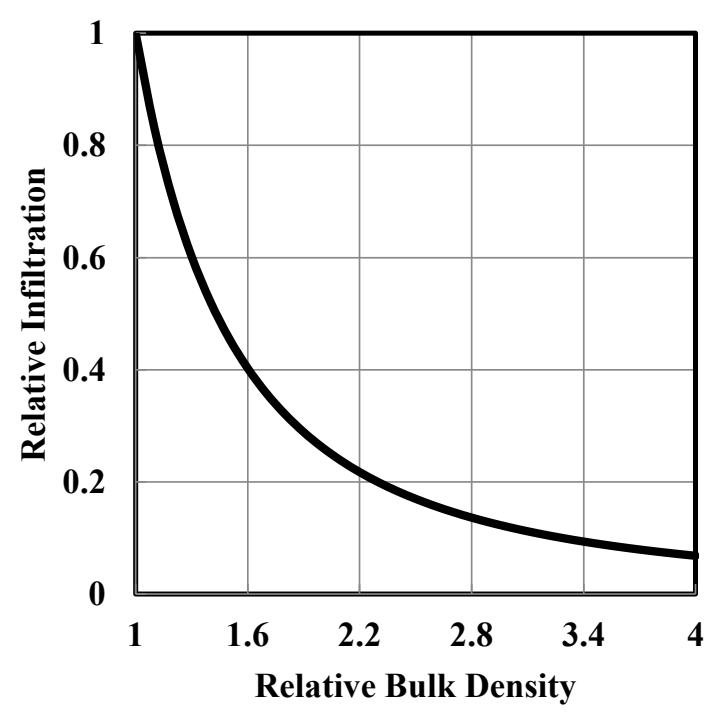

Figure (9): The relationship of the relative infiltration with the relative bulk density.
From a comparison between Figure (5) and Figure (9), the effect of relative bulk density is much greater than that of relative initial moisture content on relative infiltration.

\subsection{Effect of soil texture on infiltration}

Figure (10) shows the relationship between the cumulative infiltration depth and infiltration time for different soil textures having an initial soil moisture content of $10.5 \%$ and a bulk density of $1.45 \mathrm{gm} / \mathrm{cm}^{3}$. The accumulative infiltration depth increases with time and with increasing coarse soil particles, as shown in Figure (10). Figure (11) presents the relationship between the infiltration rate and infiltration time with a bulk density of 1.45 $\mathrm{g} / \mathrm{cm}^{3}$ and an initial moisture content of $10.5 \%$ for soils of different textures. The Figure shows that the infiltration rate decreases with time and with decreasing coarse soil particles.

Figures (12-14) show the variation of the basic infiltration rate for different soil textures and different values of bulk density for a specified level of initial soil moisture $(3.5 \%$, $10.5 \%$, or $17.5 \%$ ), respectively. These figures show that the basic infiltration rate increases with increasing coarse soil particles and decreasing the initial soil moisture. The basic infiltration rate also increases with a decrease in bulk density, and this increase as the initial soil moisture decreases. It is also found that the effect of changing bulk density from 1.25 $\mathrm{g} / \mathrm{cm}^{3}$ to $1.65 \mathrm{~g} / \mathrm{cm}^{3}$, indicating the change in soil structure, on the basic infiltration rate is greater than the change in soil texture from clay to other textures up to the sandy mix.

The basic infiltration rate value for the soil texture at a specific initial moisture and bulk density was determined by calculating the rate of basic infiltration rate values for a group of soils that consist of varying proportions of sand, silt, and clay but represent the same texture.

Figure (15) shows the relationship between the relative infiltration and relative sand value, the relative infiltration defined 


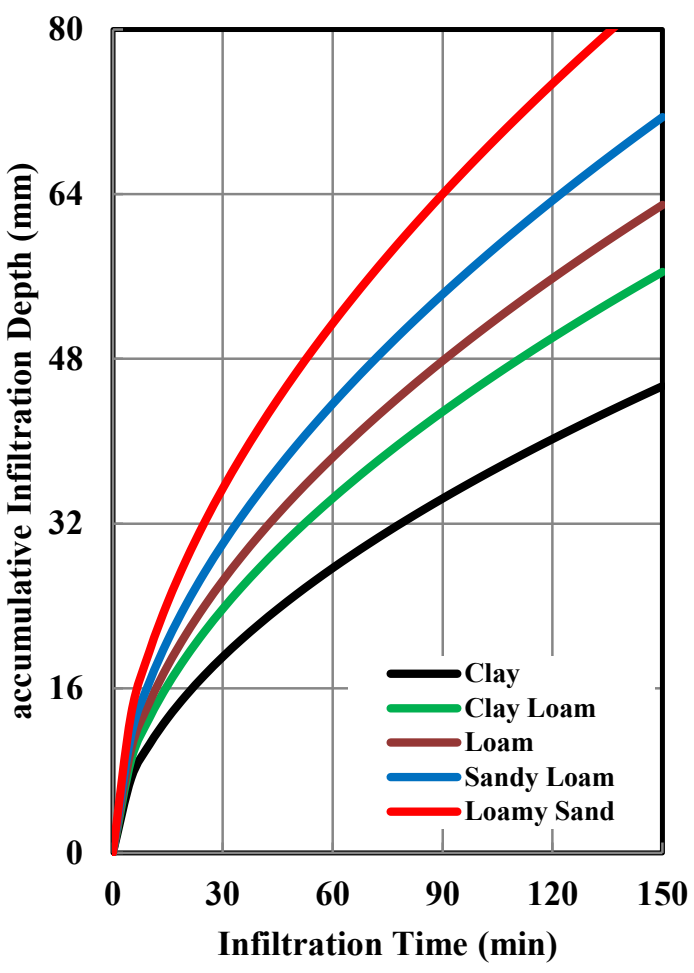

Figure (10): The relationship of the cumulative infiltration depth with time for different soil textures having initial soil moisture content of $10.5 \%$ and a bulk density of $1.45 \mathrm{gm} / \mathrm{cm}^{3}$.

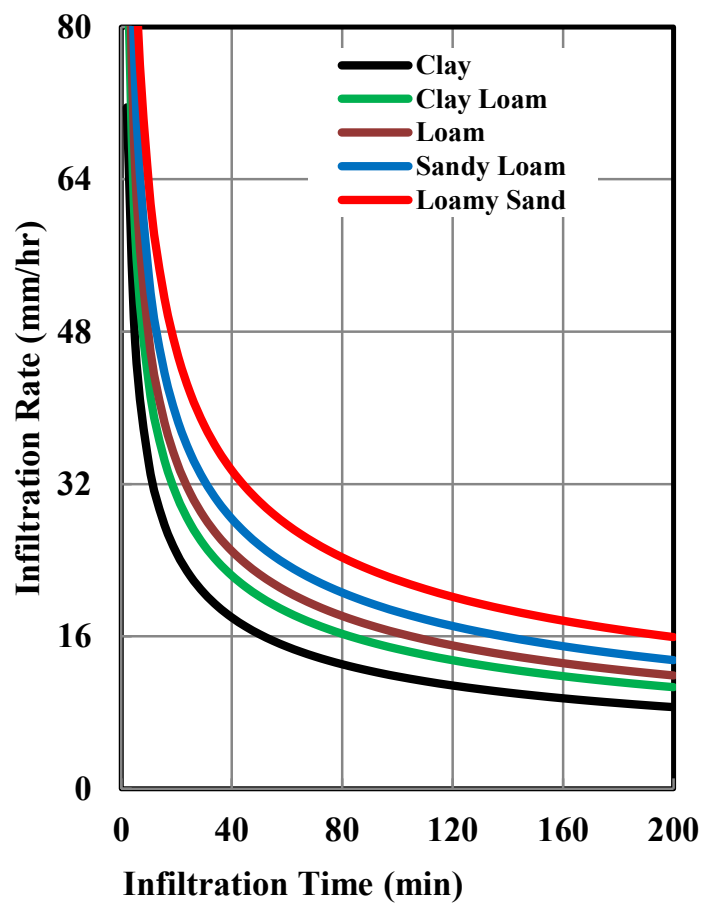

Figure (11): The relationship of the infiltration rate with time for different soil textures having initial soil moisture content of $10.5 \%$ and a bulk density of $1.45 \mathrm{gm} / \mathrm{cm}^{3}$.

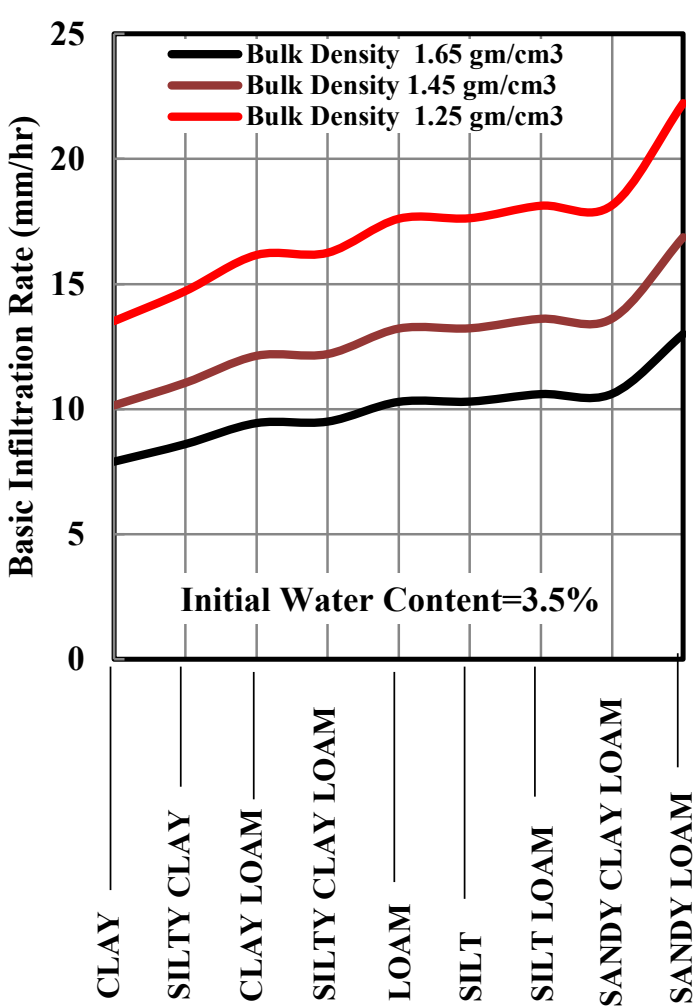

Figure (12): The variation of the basic infiltration rate for different soil textures having initial moisture of $3.5 \%$ at different values of bulk density.

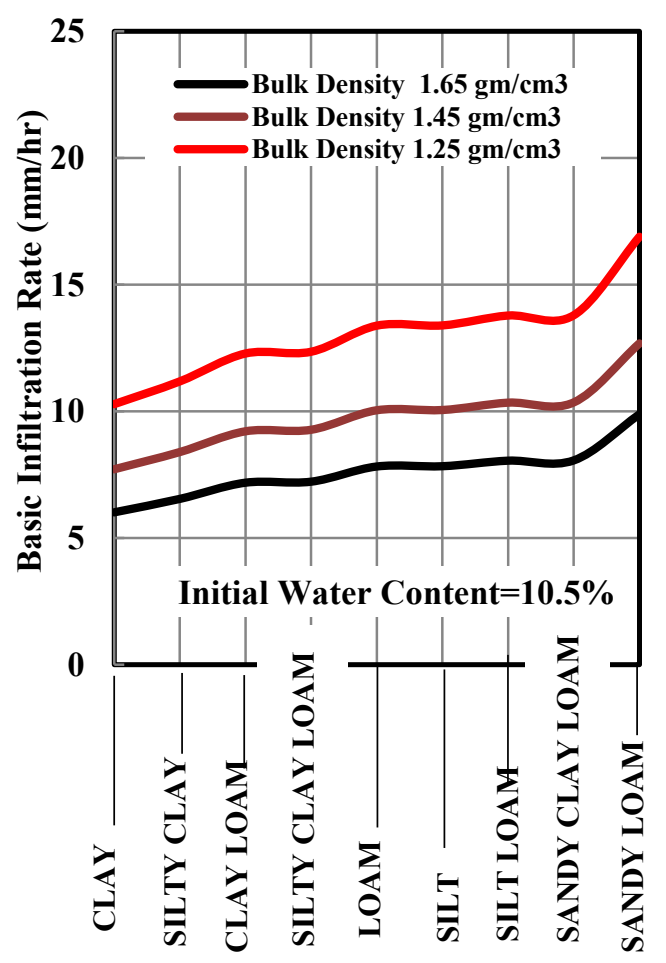

Figure (13): The variation of the basic infiltration rate for different soil textures its initial moisture $10.5 \%$ at different values of bulk density. 


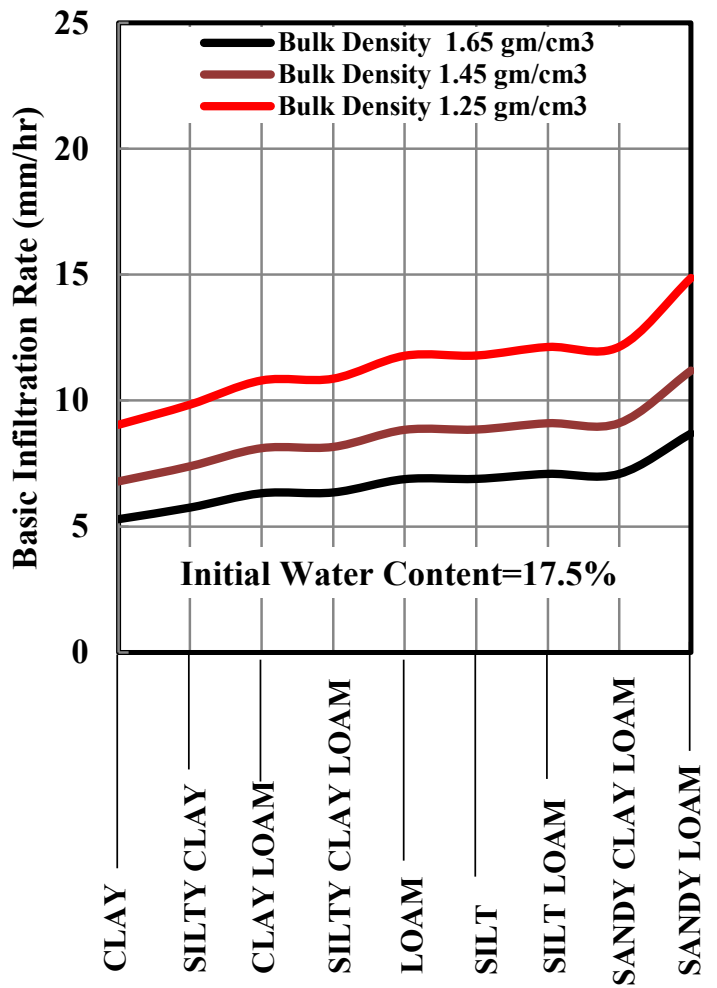

Figure (14): The variation of the basic infiltration rate for different soil textures having initial moisture of $\mathbf{1 7 . 5 \%}$ at different values of a bulk density.

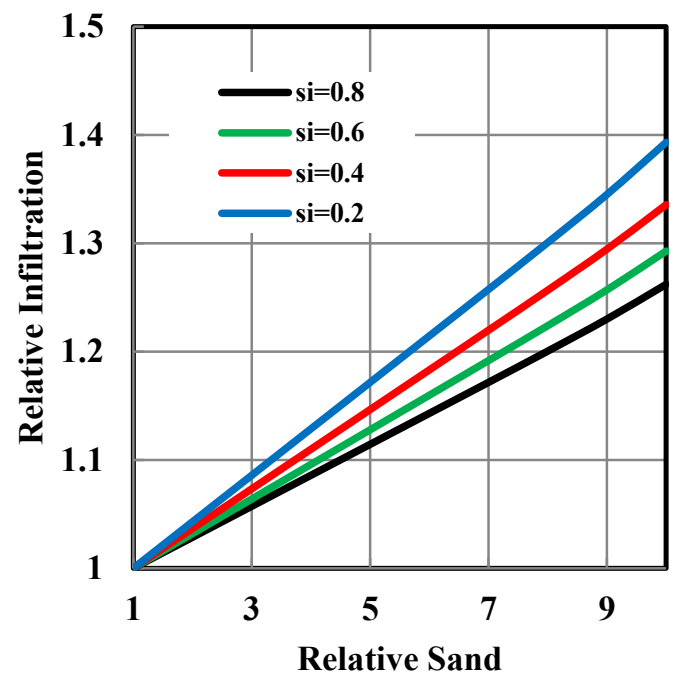

Figure (15): The relationship of the relative infiltration with the relative sand for different values of the silt.

above, the relative values of sand are $\left(\frac{S a_{0}}{S a_{0}}, \frac{S a_{1}}{S a_{0}}, \frac{S a_{2}}{S a_{0}}, \frac{S a_{3}}{S a_{0}}, \ldots\right)$. Based equations 4 and 5 at the same infiltration time and equation 6 results:
$\frac{D_{i}}{D_{0}}=\frac{I_{i}}{I_{0}}=\frac{I b_{i}}{I b_{0}}=\left[\quad 51.734 * \mathrm{Sa}_{\mathrm{i}}{ }^{12.366}-3.271 *\right.$

$\left.\mathrm{Si}^{22.978}-1.169 *\left(1-\mathrm{Si}_{-}-\mathrm{Sa}_{\mathrm{i}}\right)+2.24\right] /[51.734$ *

$\left.\mathrm{Sa}_{0}{ }^{12.366}-3.271 * \mathrm{Si}^{22.978}-1.169 *\left(1-\mathrm{Si}-\mathrm{Sa}_{0}\right)+2.24\right]$

......(9)

Equation (9) is presented in Figure (15), in which it is clear that the relative infiltration, whether it is the relative cumulative infiltration depth, relative infiltration rate, or relative basic infiltration rate, increases with the increase in the relative sand values according to Equation 9 , and this increase is greater at the smaller silt percentage.

\section{CONCLUSION:}

* Devising an empirical equation to estimate the cumulative infiltration depth, infiltration rate, and basic infiltration rate as a function of the initial moisture, soil bulk density, and the soil proportions of sand, silt, and clay.

*Relative infiltration, whether it is relative cumulative infiltration depth, relative infiltration rate, or relative basic infiltration rate, decreases with increasing relative initial moisture content or relative bulk density, and increases with increasing relative sand values.

\section{REFERENCES:}

[1] A.Y. Hachum and H.I.Yasin, "On-farm Irrigation Systems Engineering”, Dar Al Kuttb for Printing and Publishing, Mosul University, Mosul, Iraq. 1992.

[2] R. Alhassoun, "Studies on factors affecting the infiltration capacity of agricultural soils", Institut for Pflanzenbau und Bodenkunde, Dissertationen aus dem Julius KühnInstitut, Bundesforschungsinstitut für Kulturpfl anzen, 2009.

[3] X. Qing, H. Haojie, X. Jinran, Z. Caixia, Z. Zhiliang, H. Huiqiang, and Z. Qin, "Research Progress of Soil Water Infiltration", E3S Web of Conferences 189, $01006 \quad$ (2020), https://doi.org/10.1051/e3sconf/20201890 $\underline{1006}$ 
[4] AN. Kostiakov. "On the dynamics of the coefficient of water percolation in soils and the necessity of studying it from the dynamic point of view for the purposes of amelioration. Trans. Sixth Comm". Int. Soc.Soil Sci. . 1:7-21.1932;

[5] H. I. Yasin, and E. M. Ghazal, "Estimation of Infiltration Data for Different Initial Soil Water Content", Anbar Journal for Engineering Sciences AJES- Vol.6, No. 2, 297-306. 2013.

[6] M. Rashidi, A. Ahmadbeyki and A. Hajiaghaei, "Prediction of Soil Infiltration Rate Based on Some Physical Properties of Soil", American-Eurasian J. Agric. \& Environ. Sci., 14 (12): 13591367, 2014.

[7] T.P. Ghanshyam, T. T. Sikar, K. S. Rawat, and S. K. Singh, "Estimation of Infiltration Rate from Soil Properties Using Regression Model for Cultivated Land", Geology, Ecology, and Landscapes, $\quad 3: 1, \quad 1-13$, DOI: 10.1080/24749508.2018.1481633. 2019.

[8] F. A. Adeniji, B. G. Umara, J. M. Dibal, and A. A. Amali, "Variation of Infiltration Rates with Soil Texture, A Laboratory Study", International Journal of Engineering and Innovative Technology (IJEIT) Volume 3, Issue 2, August 2013.

[9] Q.M. Bakir, "Wetting Pattern for Dual Line Trickle Sources". M.Sc. thesis, College of Engineering, University of Mosul, Iraq.55p. 2019.

[10] S.M. Kharoofa, "The Effect of Pulsed Sprinkler Irrigation on Infiltration". M.Sc. thesis, College of Engineering, University of Mosul, Iraq.66p. 2020.
[11] A.K. Mohammed, "Study of Wetting Front Advance of line Subsurface Drip Source ". M.Sc. thesis, College of Engineering, University of Mosul, Iraq.90p. 2020.

[12] Y.M. Hasan, "Water Infiltration under Sprinkling Application for Some Iraqi Soils". M.Sc. thesis, College of Engineering, University of Mosul, Iraq.101p. (1983).

[13] Hamadamin, K.K. "Infiltration Rate Characteristics of Gypsiferous Soils in Northern Iraq ".M.Sc. thesis, College of Engineering, University of Mosul, Iraq.101p. (1984)

[14] A.Y. Hachum, and E. M. Ghazal, "Effect of Soil Moisture Content on the Infiltration Function". Mutah lil-buhooth wa-dirasat journal, Vol. 8, No. 6. 1993

[15] Daham, F.A. "Infiltration into Two Layered Soil Profiles under Ponded Condition". M.Sc. thesis, College of Engineering, University of Mosul, Iraq. 95p, 1986.

[16] H. I. Yasin, "Effect of Intermittent Water Application from Trickle Source on Water Movement and Moisture Distribution in Layered Soil", Ph.D. Thesis, Mosul University, Iraq. $80 \mathrm{p}$ .2006 . 


\section{الارتشاح وبعض صفات التربة الفيزيائية}

\author{
انتصار نحما غزال \\ entesarzal@gmail.com
}

حقي إسماعيل ياسين

haqqiismai156@gmail.com

جامعة الموصل ـ كلية الهندسة ـ قسم هندسة السدود و الموارد المائية

الخلاصة

يهدف البحث الى دراسة تأثير بعض صفات التربة الفيزيائية كمكونات التربية من رمل وغرين وطين والكثافة الظاهرية للتربة.

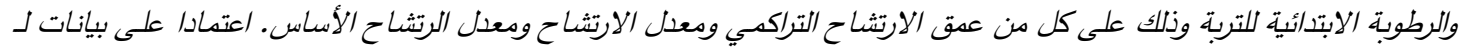

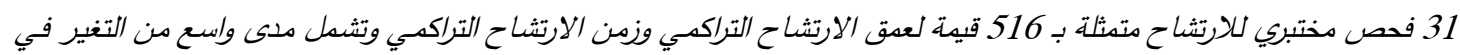

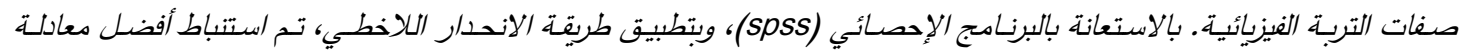

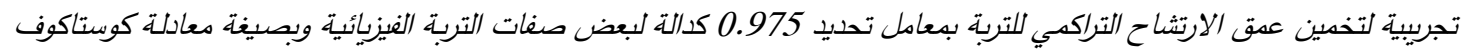
التشمل تخمين معدل الارتشاح الاساس. الكلمات الدالة: الارتشاح، رطوبة التربة الابتدائية، الكثافة الظاهرية، نسجة التربة. 